\title{
Effect of Macroeconomic Determinants on Indian Stock Market
}

\author{
Krishna Gadasandula \\ Associate Professor, Department of Accounting and Finance \\ ICBM-School of Business Excellence, Hyderabad, Telangana, India \\ E-Mail: krishnagadasandula@gmail.com
}

\begin{abstract}
Stock market is one of the important forms of investment. The prices of stock markets are affected by much macro-economic factors. The study investigates the relationships between the Indian stock market index (NSE Nifty) and four macroeconomic variables, namely, GDP, Inflation, Exchange Rate and Bank Rate. The data is collected on a quarterly basis for the time period March 2000 to December 2017. The study employs the Johansen's cointegration approach to the long-run equilibrium relationship between stock market index and macroeconomic variables. For causality analysis, the study carried out Granger and Geweke causality tests. From this paper it is observed that the Granger causality test results do not demonstrate the presence of any bidirectional causality. The results show the unidirectional causal associations running from GDP to Inflation, Bank Rate to GDP, Exchange Rate to GDP, NIFTY Index to GDP, Exchange Rate to Inflation, NIFTY Index to Inflation, and Bank Rate to NIFTY Index. Apart from that, the results also show no causal association between Inflation and Bank Rate, Bank Rate and Exchange Rate, and Exchange Rate and NIFTY Index. However, the bidirectional causal associations appear. When we look into the results of Geweke causality analysis shows that bidirectional causal associations exist between Inflation and Bank Rate, and Exchange Rate and Nifty Index.
\end{abstract}

Keywords: Macroeconomic Variables, Determinants of Indian Stock Market Index (NSE Nifty), Johansen's Co-integration Test, Granger Causality Test, and Geweke Causality Test for Macroeconomic Determinants

\section{INTRODUCTION}

Mark Twain once divided the world into two kinds of people: those who have seen the famous Indian monument, the TajMahal, and those who haven't. The same could be said about investors. There are two kinds of investors: those who know about the investment opportunities in India and those who don't. India may look like a small dot to someone in the U.S., but upon closer inspection, you will find the same things you would expect from any promising market, and this research is of about how the stock market got affected in by macro- economic determinants like GDP, Inflation, Exchange rate and Bank Rates. Stock market plays an important role in the economy as it helps in diversifying the investments. However, to perform the role, Indian Stock Market has significant relationship with the Indian economy.

\section{REVIEW OF RELEVANT LITERATURE}

Gurmeet Singh (2016) used Johansen co integration test, VECM, Granger causality framework for the data collected in the period from Jan 2007 to March 2014 and concluded that, in the long run stock prices positively react to money supply, Wholesale price index, and interest rate. Also found that stock prices negatively reacted towards index of industrial production and exchange rate and also stated result that Money supply causes impact only in long run but not in short run. Rosy Kalra (2012) used regression and correlation analysis for the data collected in the period from Jan 2001 to Dec 2009 analysed and concluded that, WPI, inflation are the important variables that affecting the Indian Stock Market. Pushpa Trivedi, Samar Ranjan Behera (2012) used Vector Autoregressive (VAR) framework co integration and Vector Error correction Model (VECM), Johansens Multivariate Co integration test and concluded that Index of Industrial Production react positively towards equity prices and there is negative relation between wholesale price index and equity prices. Atsuyuki Naki, Tarun Mukherjee, David Tuffle (1998) applied statistical tools like Johansen VECM, Multiple correlation and explained that Index of Industrial Production (IIP) is exhibiting positive relation whereas inflation is exhibiting negative relationship towards Indian stock market.

Aman Srivastava (2010) used the statistical tools like VECM, Johansen co integration test and concluded that domestic factors that affect the Indian stock market in long run are WPI, IIP, Inflation rate, IIP, WPI, and interest rate has highest influence on Indian stock prices in the long run whereas exchange rate influence is less on stock prices.SVD Nageswara rao, Vishnu S Ramachandran (2009) applied KCAPM and explained that, well traded stocks are getting affected by inflation. Kedarnath Mukarjee and Rk Mishra (2007) collected data for the period from 1990 to 2005, and it isstated that volatility in exchange rate is statistically important in unidirectional relationship among markets. Only few variables show significant explanatory power in the evolution of contemporaneous intermarket relation among foreign countries and India. Anita Mirchandani (2008) showed that exchange rate exhibited correlation between many other variables like interest rate, GDP, inflation in either indirect or direct manner. Exchange rate and interest rate exhibited strong indirect correlation. GDP and exchange rate displayed mild direct correlation and very weak correlation is found between exchange rate and current account balance. Hirak Ray (2008) applied Granger causality test and analysed that in long run exchange rates are positively related towards stock prices. V.Prabhakaran (2014) applied regression analysis and ANOVA for the data 
collected from 2009 to 2011 and concluded that, exchange rate has significant affect and it shows adverse effect towards Indian stock market. PankajSinha, DeeptiKohli (2015) collected data from 2006-2012 and explained that no inter-relationship is found between daily returns in foreign exchange and stock market. D.V.Lokeswar Reddy (2012) applied regression analysis for the data collected from 19972009.Regression analysis proved that macroeconomic variables accounted for $95.6 \%$ variation in stock prices. This paper also revealed that inflation rate and GDP have positive impact, and interest rate has negative impact on stock market. T.Sampath (2011) used ARDL approach for the data collected from 1993 to 2010 analysed that in long run there is positive relation between economic growth and stock prices, Exchange rate, IIP, and WPI have statistically significant impact on stock prices. Naik Pramod Kumar, Padhi Puja (2012) used Johansen co integration test, VECM for the data collected from the year 1994 to 2011 and the analysis revealed that macroeconomic variables and stock market are co integrated and hence long-run relation exists between them. Money supply, IIP reacts positively but inflation reacts negatively towards stock prices. It is also found that unidirectional causality from stock price to inflation, interest rate to stock prices, and money supply to stock prices.

Sydney ludvigson and Charles steindel (1999) says that there will be changes in spending pattern, savings of the people and wealth maximisation have an impact on stock market. As the workers and employees income increases then the consumption and investment pattern varies/changes. Sarikamahajan and Balwinder Singh (2008) found that there is a positive relationship between the stock volatility and business volume by using linear and nonlinear terms and modules. Dharmendra Singh (2010) the main aim this paper is to analyse to know the causal relationship between the macroeconomic determinants like exchange rate, wholesale price index, industrial production, and BSE by using granger causality tests, and also used bilateral causal relationship in case of sensex and IIP and concluded that, through IIP it can anticipate the stock market movement.

Samveg Patel (2012) this paper analysed the effects of macroeconomic variables like exchange rate, money supply, gold prices, silver prices, inflation, and crude oil prices on Indian stock market by using granger causality tests, unit root test, co integration test, vector correction model and concluded that macro-economic factors shows more impact on Indian stock market. Dhaneesh kumar $\mathrm{T} \mathrm{K}$ and $\mathrm{P} \mathrm{K}$ Sudarsan (2015) study concluded that exchange rate plays an important role in country's BOP. The increase and decrease of imports and exports are depend on exchange rate and therefore shows a negative sign for exchange rate and international business. Ronit mukherji (2015)the study analysed the interest rates, inflation, index of industrial production, and balance of trade, and concluded that external variables shows more impact on Indian stock market.
Archanagoel (2016) study used multiple linear regression models to know the dividend policy and this dividend policy of the companies changes due to change in these macroeconomic determinants like interest rates, wholesale price index, industrial production, inflation. The more the income earns by the company the higher dividends will be get for the shareholders. Dr.Gaurav Agrawal, Aniruddh kumar srivastav and Ankitasrivastava (2012) the study analyzed about the changes in nifty returns and Indian rupee \& US dollar exchange rate, and concluded that, when exchange rate increases, exporters lose their business/rivalry in international market and revenue of exporters tends to decline. Monomita Nandy (2008) has done a study on how capital structure affect the Indian stock market and concluded that Indian stock market also effect with the capital structure followed by the companies. Monomita Nandy (2013) found that $92 \%$ of the companies felt that, if the demand of company share start decreasing then there is influence on stock market performance, and it also concluded that the stock market get influence based on balancing of debt- equity of the company. Dr. P.S. Vohra \& Ms. Preeti Sehgal (2012) studied for the period from 1951 to 2011 and found that foreign investors also play a vital role in Indian capital market, also concluded that, the three major challenges like capital inflows, Global slowdown and Foreign Institutional Investors (FII) are the key role players of the Indian stock market. Varsha Ingalhalli, Poornima B. G.\&Y. V. Reddy(2015)done a study on dynamic relationship between Oil, Gold, Forex and Stock markets in Indian context from the period January 2005 to July 2016 and found that in past years Indian financial market influence the Indian stock market. Santosh Kumar, Raju G and Tanveer Shahab (2013) investigated on the contagion effect of dollar and euro on the Indian stock market by collecting the data of last 10 years from 2002to 2012 and found that, the exposure of euro is vindicated only in large and most liquid stocks as compared to wider exposure of dollar. Manish Kumar investigated in 2014on oil prices and exchange rate, which are affecting the Indian stock market and found that, stock prices, exchange rates and oil prices are not co integrated.

The researcher used the Spillover Index Methodology. Karam Pal and Ruhee Mittal of Haryana School of Business investigated in 2011. The researcher used the data from January 1995 to December 2008 and with the help of the Unit root test, the co-integration test and error correction mechanism (ECM) they found that there is co-integration between macroeconomic variables and Indian stock indices, which is indicative of a long-run relationship and rate of inflation has an impact on both BSE Sensex and S\&P CNX Nifty. Pretorius (2013) found in order to determine which factors influence the correlation between two stock markets. A cross section and a time-series regression model were estimated using data for the period from 1995 to 2000.The results showed that only the extent of bilateral trade and the industrial production growth differential were significant in explaining the correlation between two countries on a crosssectional basis. 


\section{OBJECTIVES OF THE STUDY}

1. To analyze the relationship between macroeconomic determinants and Indian stock market.

2. To unravel out the nature of causal relationship that exists between the stock market and economic variables.

\section{RESEARCH METHODOLOGY}

The secondary data on selected macroeconomic variables were collected on quarterly basis during the period March 2000 to December 2017 from the sources like Handbook of statistics on Indian economy maintained by Reserve Bank of India (RBI),National Index of First fifty (NIFTY), International financial statistics maintained by International Monetary Fund, Center For Monitoring Indian Economy (CMIE),Ministry of Statistics and Planning Implementation in India (MOPSI), and website of Worldbank.org Descriptions of variables and data sources are presented in Table I. All variables are converted into natural logarithmic form. The standard procedures of unit root test namely the Augmented Dickey Fuller (ADF), Philips-Perron (PP), and Zivot-Andrews (ZA) unit root tests are performed to check the stationary nature of the series. Johansen-Julius co integration test is carried out in order to find the co integration between the variables. The study also carried out Granger and Geweke causality tests for causality analysis.

TABLE I DATA COLLECTED FOR THE PERIOD OF 15 YEARS ON QUARTERLY BASIS

\begin{tabular}{|c|c|c|c|c|c|c|c|}
\hline Year & Month & Time & GDP & Inflation & Bank Rate & Exchange Rate & Nifty Index \\
\hline 2000 & Mar & 1 & 5.79 & 4.80 & 8.00 & 43.52 & 1528.45 \\
\hline 2000 & June & 2 & 5.31 & 5.20 & 7.00 & 44.53 & 1471.45 \\
\hline 2000 & Sept & 3 & 6.67 & 3.50 & 8.00 & 45.82 & 1271.65 \\
\hline 2000 & Dec & 4 & 4.30 & 2.30 & 8.00 & 46.70 & 1263.55 \\
\hline 2001 & Mar & 5 & 1.81 & 5.60 & 7.00 & 46.52 & 1148.20 \\
\hline 2001 & June & 6 & 4.43 & 5.50 & 7.00 & 46.91 & 1107.90 \\
\hline 2001 & Sept & 7 & 5.33 & 5.90 & 7.00 & 47.51 & 913.85 \\
\hline 2001 & Dec & 8 & 6.40 & 5.10 & 6.50 & 47.81 & 1059.05 \\
\hline 2002 & Mar & 9 & 6.75 & 4.80 & 6.50 & 48.37 & 1129.55 \\
\hline 2002 & June & 10 & 5.20 & 4.10 & 6.50 & 48.86 & 1057.80 \\
\hline 2002 & Sept & 11 & 5.66 & 4.10 & 6.50 & 48.35 & 963.15 \\
\hline 2002 & Dec & 12 & 1.71 & 2.80 & 6.30 & 48.04 & 1093.50 \\
\hline 2003 & Mar & 13 & 3.80 & 3.80 & 6.30 & 47.55 & 978.20 \\
\hline 2003 & June & 14 & 5.51 & 3.70 & 6.00 & 46.63 & 1134.15 \\
\hline 2003 & Sept & 15 & 8.85 & 2.90 & 6.00 & 45.75 & 1417.10 \\
\hline 2003 & Dec & 16 & 11.03 & 4.00 & 6.00 & 45.49 & 1879.75 \\
\hline 2004 & Mar & 17 & 8.38 & 3.40 & 4.50 & 44.93 & 1771.90 \\
\hline 2004 & June & 18 & 8.30 & 3.40 & 4.50 & 45.40 & 1505.60 \\
\hline 2004 & Sept & 19 & 7.10 & 4.00 & 4.50 & 45.97 & 1745.50 \\
\hline 2004 & Dec & 20 & 5.50 & 3.60 & 6.00 & 43.89 & 2080.50 \\
\hline 2005 & Mar & 21 & 9.00 & 4.00 & 6.00 & 43.58 & 2035.65 \\
\hline 2005 & June & 22 & 9.40 & 3.90 & 6.00 & 43.47 & 2220.60 \\
\hline 2005 & Sept & 23 & 8.90 & 4.80 & 6.00 & 43.80 & 2601.40 \\
\hline 2005 & Dec & 24 & 9.60 & 5.70 & 6.25 & 45.53 & 2836.55 \\
\hline 2006 & Mar & 25 & 9.90 & 5.00 & 6.50 & 44.48 & 3402.55 \\
\hline 2006 & June & 26 & 9.30 & 6.50 & 6.75 & 46.06 & 3128.20 \\
\hline 2006 & Sept & 27 & 9.80 & 6.60 & 7.00 & 46.12 & 3588.40 \\
\hline 2006 & Dec & 28 & 9.40 & 6.90 & 7.25 & 44.63 & 3966.40 \\
\hline 2007 & Mar & 29 & 9.80 & 7.60 & 7.50 & 44.03 & 3821.55 \\
\hline 2007 & June & 30 & 9.70 & 6.10 & 7.75 & 40.77 & 4318.30 \\
\hline 2007 & Sept & 31 & 9.50 & 5.70 & 7.75 & 40.34 & 5021.35 \\
\hline 2007 & Dec & 32 & 9.60 & 5.10 & 7.75 & 39.44 & 6138.60 \\
\hline 2008 & Mar & 33 & 8.60 & 6.00 & 7.75 & 40.36 & 4734.50 \\
\hline
\end{tabular}




\begin{tabular}{|c|c|c|c|c|c|c|c|}
\hline 2008 & June & 34 & 9.80 & 7.30 & 7.75 & 42.82 & 4040.55 \\
\hline 2008 & Sept & 35 & 8.50 & 9.50 & 9.00 & 45.56 & 3921.20 \\
\hline 2008 & Dec & 36 & 5.80 & 9.80 & 7.50 & 48.64 & 2959.15 \\
\hline 2009 & Mar & 37 & 3.50 & 9.30 & 5.50 & 51.23 & 3020.95 \\
\hline 2009 & June & 38 & 5.90 & 9.60 & 4.75 & 47.77 & 4291.10 \\
\hline 2009 & Sept & 39 & 9.30 & 12.40 & 4.75 & 48.44 & 5083.95 \\
\hline 2009 & Dec & 40 & 7.70 & 15.50 & 4.75 & 46.63 & 5201.05 \\
\hline 2010 & Mar & 41 & 11.40 & 14.90 & 5.00 & 45.50 & 5249.10 \\
\hline 2010 & June & 42 & 9.10 & 14.10 & 5.25 & 46.56 & 5312.50 \\
\hline 2010 & Sept & 43 & 8.20 & 10.40 & 6.00 & 46.06 & 6029.95 \\
\hline 2010 & Dec & 44 & 8.70 & 8.00 & 8.58 & 45.16 & 6134.50 \\
\hline 2011 & Mar & 45 & 9.60 & 9.00 & 6.75 & 44.99 & 5833.75 \\
\hline 2011 & June & 46 & 7.60 & 9.10 & 7.50 & 44.85 & 5647.40 \\
\hline 2011 & Sept & 47 & 7.00 & 9.30 & 8.25 & 47.64 & 4943.25 \\
\hline 2011 & Dec & 48 & 6.50 & 6.40 & 8.50 & 52.67 & 4624.30 \\
\hline 2012 & Mar & 49 & 5.80 & 6.80 & 8.50 & 50.32 & 5295.55 \\
\hline 2012 & June & 50 & 4.50 & 8.00 & 8.00 & 56.03 & 5278.90 \\
\hline 2012 & Sept & 51 & 4.60 & 9.40 & 8.00 & 54.61 & 5703.30 \\
\hline 2012 & Dec & 52 & 4.40 & 11.30 & 8.00 & 54.60 & 5905.10 \\
\hline 2013 & Mar & 53 & 4.40 & 12.60 & 7.50 & 54.29 & 5682.55 \\
\hline 2013 & June & 54 & 4.70 & 12.80 & 7.25 & 59.53 & 5842.20 \\
\hline 2013 & Sept & 55 & 5.20 & 12.80 & 7.50 & 62.59 & 5735.30 \\
\hline 2013 & Dec & 56 & 4.60 & 11.20 & 7.75 & 61.81 & 6304.00 \\
\hline 2014 & Mar & 57 & 4.60 & 8.40 & 8.00 & 61.37 & 6704.20 \\
\hline 2014 & June & 58 & 5.70 & 7.70 & 8.00 & 60.56 & 7611.35 \\
\hline 2014 & Sept & 59 & 5.30 & 6.90 & 8.00 & 60.34 & 7964.80 \\
\hline 2014 & Dec & 60 & 4.60 & 5.50 & 8.00 & 62.66 & 8282.70 \\
\hline 2015 & Mar & 61 & 7.50 & 6.28 & 8.50 & 62.52 & 8491.00 \\
\hline 2015 & June & 62 & 7.50 & 6.10 & 8.25 & 63.81 & 8368.50 \\
\hline 2015 & Sept & 63 & 7.40 & 4.41 & 8.25 & 65.51 & 7948.53 \\
\hline 2015 & Dec & 64 & 7.51 & 5.00 & 8.25 & 66.29 & 7946.03 \\
\hline 2016 & Mar & 65 & 7.10 & 4.83 & 8.25 & 67.20 & 7738.32 \\
\hline 2016 & June & 66 & 7.30 & 5.77 & 8.25 & 66.65 & 8287.23 \\
\hline 2016 & Sept & 67 & 7.00 & 4.31 & 8.25 & 66.55 & 8611.12 \\
\hline 2016 & Dec & 68 & 6.10 & 5.61 & 8.25 & 67.95 & 8185.35 \\
\hline 2017 & Mar & 69 & 5.70 & 3.81 & 8.25 & 64.86 & 9173.56 \\
\hline 2017 & June & 70 & 6.30 & 1.54 & 8.25 & 64.62 & 9520.34 \\
\hline 2017 & Sept & 71 & 7.00 & 3.28 & 8.25 & 65.31 & 9788.23 \\
\hline 2017 & Dec & 72 & 6.10 & 3.41 & 8.25 & 63.84 & 10530.27 \\
\hline
\end{tabular}

\section{ANALYSIS AND FINDINGS}

All variables are converted into natural logarithmic form. And before starting with the analysis, it is required to understand the order of integration of the variables. In order to achieve this objective, the study carried out Augmented Dickey-Fuller (ADF), Philips-Perron (PP), and ZivotAndrews (ZA) unit root tests. The results are recorded in Table II. It is evident that the variables are integrated to order one, i.e. the variables are 2(1) in nature. Therefore, the study can proceed towards the co integration analysis.

Now, it is found that the variables are 2(1) in nature; it can be proceed with the co integration test. In order to find the co integration between the variables, the study has carried out Johansen-Julius co integration test. In this test, the values of Max-Lambda and Trace statistics are to be compared and the results are recorded in Table III. 
TABLE II RESULTS OF UNIT ROOT TESTS

\begin{tabular}{|l|c|c|c|}
\hline & ADF & PP & ZA \\
\hline \multicolumn{4}{|c|}{ Level } \\
\hline GDP & $-3.550^{\mathrm{a}}$ & $-3.557^{\mathrm{a}}$ & $-5.248^{\mathrm{b}}(2003 \mathrm{Q} 1)$ \\
\hline Inflation & -1.909 & -1.868 & $-3.216(2006 \mathrm{Q} 1)$ \\
\hline Bank Rate & -2.252 & -2.449 & $-3.307(2010$ Q2) \\
\hline Exchange Rate & -0.180 & -0.457 & $-3.608(2011$ Q2) \\
\hline NIFTY Index & -0.366 & -0.432 & $-4.382(2004$ Q2) \\
\hline \multicolumn{4}{|c|}{ First Difference } \\
\hline GDP & $-8.950^{\mathrm{a}}$ & $-9.275^{\mathrm{a}}$ & $-9.035^{\mathrm{a}}(2002 \mathrm{Q} 4)$ \\
\hline Inflation & $-8.279^{\mathrm{a}}$ & $-8.311^{\mathrm{a}}$ & $-8.638^{\mathrm{a}}(2009 \mathrm{Q} 4)$ \\
\hline Bank Rate & $-7.432^{\mathrm{a}}$ & $-7.431^{\mathrm{a}}$ & $-7.638^{\mathrm{a}}(2008 \mathrm{Q} 3)$ \\
\hline Exchange Rate & $-7.127^{\mathrm{a}}$ & $-7.181^{\mathrm{a}}$ & $-7.804^{\mathrm{a}}(2007$ Q4) \\
\hline NIFTY Index & $-6.432^{\mathrm{a}}$ & $-6.359^{\mathrm{a}}$ & $-7.282^{\mathrm{a}}(2007$ Q4) \\
\hline a value 1\% significance level, b value $=5 \%$ significance level $^{\mid}$
\end{tabular}

The results indicate that the reported Max-Lambda and Trace statistics are higher than the values with VAR, and hence, they indicate the presence of two co integrating vectors between the variables. Therefore, it is evident that variables are co integrating in long run.

TABLE III RESULTS OF JOHANSEN-JULIUS CO INTEGRATION TEST

\begin{tabular}{|c|l|c|c|c|}
\hline & \multicolumn{2}{|c|}{ Reported } & \multicolumn{2}{c|}{ Values in VAR } \\
\hline $\mathrm{r}$ & Max-Lambda & Trace & Max-Lambda & Trace \\
\hline 0 & $243.30415^{*}$ & $432.41341^{*}$ & 30.04 & 59.46 \\
\hline 1 & $181.47425^{*}$ & $189.10926^{*}$ & 23.80 & 39.89 \\
\hline 2 & 7.5974244 & 7.6350113 & 17.89 & 24.31 \\
\hline \multicolumn{3}{|c|}{$\mathrm{r}$ is the number of co integrating vectors (Null Hypothesis) } \\
\hline
\end{tabular}

TABLE IV RESUlts OF GRANGER CAUSALITY TEST

\begin{tabular}{|l|c|c|c|c|c|}
\hline \multirow{2}{*}{ Dependent Variables } & \multicolumn{7}{|c|}{ Independent Variables } \\
\cline { 2 - 6 } & GDP & Inflation & Bank Rate & Exchange Rate & NIFTY Index \\
\hline GDP & - & 1.6590 & $5.7115^{\mathrm{c}}$ & $7.2658^{\mathrm{b}}$ & $10.0242^{\mathrm{a}}$ \\
\hline Inflation & $5.7843^{\mathrm{c}}$ & - & 1.2920 & $5.2201^{\mathrm{c}}$ & $11.1477^{\mathrm{a}}$ \\
\hline Bank Rate & 0.6198 & 0.7390 & - & 0.7584 & 2.6919 \\
\hline Exchange Rate & 0.0669 & 0.6581 & 3.8459 & - & 2.3506 \\
\hline NIFTY Index & 1.9448 & 0.1636 & $4.8794^{\mathrm{c}}$ & 2.5395 & - \\
\hline \multicolumn{7}{|c|}{$\begin{array}{l}\text { a value at 1\% significance level } \\
\text { b value at 5\% significance level } \\
\text { c value at 10\% significance level }\end{array}$} \\
\hline
\end{tabular}

TABLE V COMPARISON BETWEEN THE RESULTS OF GEWEKE AND GRANGER CAUSALITY ANALYSIS

\begin{tabular}{|l|c|c|c|}
\hline \multirow{2}{*}{ Causality Directions } & \multicolumn{2}{c|}{ Geweke Causality results } & Granger Causality results \\
\cline { 2 - 4 } & Chi-square & Verdict & Verdict \\
\hline GDP <-> Inflation & 1.4045 & No Feedback & GDP -> Inflation \\
\hline GDP <-> Bank Rate & 0.6608 & No Feedback & GDP <- Bank Rate \\
\hline GDP <-> Exchange Rate & 1.1597 & No Feedback & GDP <- Exchange Rate \\
\hline GDP <-> NIFTY Index & 1.4712 & No Feedback & GDP <- NIFTY Index \\
\hline Inflation <-> Bank Rate & $5.9733^{\text {b }}$ & Feedback & Inflation - Bank Rate \\
\hline Inflation <-> Exchange Rate & 0.7978 & No Feedback & Inflation <- Exchange Rate \\
\hline Inflation <-> NIFTY Index & 1.3412 & No Feedback & Inflation <- NIFTY Index \\
\hline Bank Rate <-> Exchange Rate & 0.0509 & No Feedback & Bank Rate - Exchange Rate \\
\hline Bank Rate <-> NIFTY Index & 0.0285 & No Feedback & Bank Rate -> NIFTY Index \\
\hline Exchange Rate <-> NIFTY Index & $11.7765^{\text {a }}$ & Feedback & Exchange Rate - NIFTY Index \\
\hline \multicolumn{4}{|c|}{$\begin{array}{l}\text { a value at } 1 \% \text { significance level } \\
\text { b value at 5\% significance level }\end{array}$} \\
\hline
\end{tabular}

\section{CONCLUSION}

Currently, Granger-Geweke causality models have been widely applied to investigate the dynamic direction relationships among variables. From this study it is found that there is a co integrated association between the variables, so it can proceed with the causality analysis. For causality analysis, Granger and Geweke causality tests are carried out. The major reason behind applying the Geweke causality test is that, this test is more robust in determining the bidirectional causal associations for a low-frequency dataset, and thereby, it can overcome the shortcomings of the Granger causality test.

The results of causality analysis are shown in table four and five. It can be observed that the Granger causality test 
results do not demonstrate the presence of any bidirectional causality. The results show the unidirectional causal associations running from GDP to Inflation (1.6590), Bank Rate to GDP (0.6198), Exchange Rate to GDP (0.0669), NIFTY Index to GDP (1.9448), Exchange Rate to Inflation (0.6581), NIFTY Index to Inflation (0.1636), and Bank Rate to NIFTY Index (2.6919). Apart from that, the results also show that no causal association between Inflation and Bank Rate (1.2920), Bank Rate and Exchange Rate (0.7584), and Exchange Rate and NIFTY Index (2.3506). However, the bidirectional causal associations appear, when we look into the results of Geweke causality analysis. The results of Geweke causality analysis show that bidirectional causal associations exist between Inflation and Bank Rate $\left(5.9733^{\mathrm{b}}\right)$ and Exchange Rate and NIFTY Index $\left(11.7765^{\mathrm{a}}\right)$. This segment of results demonstrates the shortcoming of Granger causality test in determining the bidirectional causal association for a low frequency data. In this sense, this result is a contribution in the field of financial economics, by introducing the significance of Geweke causality analysis in determining the causal association between the parameters.

\section{REFERENCES}

[1] Trivedi, P., \&Behera, S. R. (2012). Macroeconomic Fundamentals as Determinants of Equity Prices: An Empirical Analysis for India. IUP Journal of Applied Finance, 18(3), 5-30.

[2] Singh, G. (2016). The Impact of Macroeconomic Fundamentals on Stock Prices Revised: A Study of Indian Stock Market. Journal of International Economics (0976-0792), 7(1), 78-93.

[3] Kalra, R. (2012). Impact of Macroeconomic Variables on Indian Stock Market. IUP Journal of Financial Risk Management, 9(1), 4354.

[4] Sinha, P., \&Kohli, D. (2015). Modelling Exchange Rate Dynamics in India Using Stock Market Indices and Macroeconomic Variables. Amity Global Business Review, 105-18.

[5] Prabakaran, V. (2014). Dynamic Interactions of Macroeconomic Variables and Stock Market Movements in India. Global Management Review, 8(4), 1-7.

[6] Srivastava, A. (2010). Relevance of Macro Economic factors for the Indian Stock Market. Decision (0304-0941), 37(3), 69-89.

[7] Ray, H. (2008). Dynamic Interactions of Exchange Rates, Stock Prices and Macroeconomic Variables in India. ICFAI Journal of Applied Finance, 14(8), 19-33.

[8] Rao, S. N., \&Ramachandran, V. S. (2009). Stock Returns and Macro Variables: The Indian Evidence.

[9] Mukherjee, K., \& Mishra, R. K. (2007). International Stock Market Integration and Its Economic Determinants: A Study of Indian and World Equity Markets. Vikalpa: The Journal for Decision Makers, 32(4), 29-44.

[10] Sampath.T.(2011).Macroeconomic Variables and Stock Prices InIndianan Empirical Anaysis.IUP Journal of Monetary Economics,9(4),43-55.

[11] Nandy, M. (2008). The Impact of Macroeconomic Environment Factors on Capital Structure of Indian Companies. ICFAI Journal of Management Research, 7(1), 37-51.

[12] Vohra, P. S., \&Sehgal, P. (2011). An Inclusive Study of Foreign Investment in the Indian Economy. Asia Pacific Journal of Research In Business Management, 2(6), 268-281
[13] Li, N., Ayling, D. E., \&Hodgkinson, L. (2003). An examination of the information role of the yield spread and stock returns for predicting future GDP. Applied Financial Economics, 13(8), 593.

[14] Ingalhalli, V., G., P. B, \& Reddy, Y. V. (2016). A Study on Dynamic Relationship between Oil, Gold, Forex and Stock Markets in Indian Context. Paradigm (09718907), 20(1), 83-91.

[15] Kumar, S., Raju, G., \&Shahab, T. (2012). Contagion Effect of Dollar and Euro on the Indian Stock Market. IUP Journal of Applied Finance, 18(3), 84-94.

[16] KUMAR, M. (2014). The Impact of Oil Price Shocks on Indian Stock and Foreign Exchange Markets. Money \& Finance, 57-88.

[17] Pal, K., \& Mittal, R. (2011). Impact of macroeconomic indicators on Indian capital markets. The Journal of Risk Finance, 12(2), 84-97.

[18] Aduda, J., Masila, J. M., \&Onsongo, E. N. (2012). The determinants of stock market development: The case for the Nairobi Stock Exchange. International Journal of Humanities and Social Science, 2(9), 214-230.

[19] Adjasi, C., Harvey, S. K., \&Agyapong, D. A. (2008). Effect of exchange rate volatility on the Ghana Stock Exchange. African Journal of Accounting, Economics, Finance and Banking Research, 3(3).

[20] Agu C and Agu C C (2010), "Shaky Pillars: Are Micro and Macroeconomic Fundamentals Enough to Explain the Strength of the Nigeria Stock Exchange?'International Research Journal of Finance and Economics, 40, 74-86.

[21] Dornbusch, R., \& Fischer, S. (1980). Exchange rates and the current account. The American Economic Review, 70(5), 960-971.

[22] Pretorius, E. (2002). Economic determinants of emerging stock market interdependence. Emerging Markets Review, 3(1), 84-105.

[23] Goel, A. (2016). Impact of Macro-economic Variables: Dividend Policy of Indian Companies. SCMS Journal of Indian Management, 13(2), 111-12.

[24] Bhattacharya, S. N., \&Dasa, J. K. (2014). Macroeconomic Factors and Stock Market Returns: A Study in Indian Context. Journal of Accounting, Business \& Management, 21(2), 71-84.

[25] Ngalhalli, V., G., P. B.,\& Reddy, Y. V. (2016). A Study on Dynamic Relationship between Oil, Gold, Forex and Stock Markets in Indian Context. Paradigm (09718907), 20(1), 83-91.

[26] Baranidharan, S., \&Vanitha, S. (2015). The Impact of Macroeconomic Variables on Indian Stock Market using Factor Analysis Approach. IPE Journal of Management, 5(2), 38-56.

[27] Mangala, D., \& Rani, A. (2015). Revisiting the Dynamic Relationship between Macroeconomic Fundamentals and Stock Prices: Evidence from Indian Stock Market. International Journal of Financial Management, 5(3), 53-63.

[28] Nagaraja, P.,(2013). A Study on Volatility of Share Prices With Respect To Economic Factors. Asia Pacific Journal of Research in Business Management, 4(3), 1-2.

[29] Tower, E., \& Courtney, M. M. (1974). Exchange Rate Flexibility and Macro-Economic Stability. Review of Economics \& Statistics, 56(2), 215.

[30] Patel, S. A. (2013). Causal Relationship between Stock Market Indices and Gold Price: Evidence from India. IUP Journal of Applied Finance, 19(1), 99-109.

[31] Mahajan, S., \& Singh, B. (2008). Trading Volume and Return Volatility Dynamics in Indian Stock Market. ICFAI Journal of Applied Finance, 14(2), 53-73.

[32] Dhaneesh Kumar, T. K., \&Sudarsan, P. K. (2015). Rupee Volatility and Its Impact on the Macroeconomic Variables of India. IUP Journal of Applied Economics, 14(4), 27-41.

[33] Mukherji, R. (2015). What Determines Stock Returns? A Comparative Study of the Effects of Fiscal, Monetary and Trade Variables. IUP Journal of Applied Economics, 14(1), 33-46. 